\title{
PTPN11 wt Allele
}

National Cancer Institute

\section{Source}

National Cancer Institute. PTPN11 wt Allele. NCI Thesaurus. Code C49518.

Human PTPN11 wild-type allele is located within 12q24 and is approximately $91 \mathrm{~kb}$ in length. This allele, which encodes tyrosine-protein phosphatase non-receptor type 11 protein, is involved in the dephosphorylation of protein-tyrosine phosphates. The PTPN11 gene is associated with severe congenital neutropenia as well as several forms of leukemia. 